УДК 343.13:341.45(477)

DOI https://doi.org/10.32837/pyuv.v0i1.742

О. І. Коваль

orcid.org/0000-0002-6666-2467

аспірант кафедри крилінального процесу

Національної акаделії внутрішніх справ

\title{
СТАНОВЛЕННЯ ІНСТИТУТУ МІЖНАРОДНОГО СПІВРОБІТНИЦТВА У КРИМІНАЛЬНОМУ ПРОЦЕСУАЛЬНОМУ ЗАКОНОДАВСТВІ УКРАЇНИ
}

Вступ. Інститут міжнародного співробітництва у кримінальному процесі відіграє надзвичайно важливу роль у формуванні та встановленні відносин із компетентними органами іноземних держав відповідно до міжнародних норм.

Значний рівень злочинності, яка невпинно продовжує зростати, швидкий розвиток наукових технологій є тими чинниками, які дають змогу особам, що вчинили кримінальне правопорушення, переховуватися від органів правосуддя за кордоном, що має наслідком залучення національними уповноваженими суб'єктами до співпраці компетентних органів іноземних держава і навпаки.

Тому заради досягнення основних цілей судочинства у кримінальному процесі існує інститут міжнародного співробітництва. Саме він охоплює ту сферу кримінальної процесуальної діяльності уповноважених суб'єктів, яка полягає у збиранні доказів на території України та за її межами, перейнятті кримінального провадження для подальшого здійснення досудового та судового провадження, видачі правопорушників, що вчинили кримінальне правопорушення, i, врешті-решт, визнання та виконання вироків судів іноземних держав та передачу засуджених осіб. Для того, щоб краще зрозуміти, що ж являє собою цей інститут та яка правова основа його регулювання, необхідно простежити генезу його розвитку.

Мета статті - дослідити становлення міжнародного співробітництва у кримінальному процесуальному законодавстві України.

Дослідження та публікації. Питанню вивчення міжнародного співробітництва у кримінальному провадженні присвятили свої праці та публікації такі вчені, як Ю. Аленін, О. Виноградова, Т. Гавриш, Л. Гарбовський, М. Карпенко, А. Маланюк, В. Маляренко, М. Михеєнко, А. Підгородинська та інші.

Окремі проблеми форм його здійснення у своїх роботах висвітлили Є. Блажівський, I. Козьякова, М. Погорецький, Ю. Чорноус, М. Карпенко, О. Толочко, Н. Рибалка, О. Татаров, Л. Фролова, I. Чернишенко, С. Чернявський та інші.

Виклад основного матеріалу. Дослідження інституту міжнародного співробітництва у кримінальному процесуальному законодавстві неможливо здійснювати без дослідження історичного розвитку країни та праць учених-процесуалістів.
Зважаючи на тенденцію розвитку кримінального процесуального законодавства, питання здійснення міжнародного співробітництва у кримінальному провадженні залишається все ще актуальним, тому необхідно дослідити процес його формування, розвитку та закріплення в законодавстві України.

На процес становлення міжнародного співробітництва з іноземними державами на території України завжди впливали економічна та політична ситуації в державі, стрімкий розвиток технологій, ріст злочинності, яка набувала все більш міжнародного характеру та надавала можливість злочинцям переховуватися від кримінального переслідування поза межами території проживання тощо.

Для України ж новий етап у розвитку кримінального процесуального законодавства розпочався з моменту створення у грудні місяці 1917 року Української Соціалістичної Радянської Республіки (далі - УСРР), що зумовило необхідність в його оновленні та упорядкуванні з урахуванням вимог тогочасної політики [1].

Тому одним із засобів приведення норм у відповідність стала повна кодифікація норм різних галузей права, яка не оминула і кримінально-процесуальне законодавство.

Перший Кримінально-процесуальний кодекс УСРР (далі - КПК УСРР) прийнято 13 вересня 1922 року. Характеризуючи КПК УСРР 1922 року, С.О. Сорока, Г.С. Римарчук слушно зазначають, що «значення його полягало в тому, що він проголошував такі демократичні засади, як: гласність, усність і безпосередність судового процесу, його змагальність; провадження процесу мовою більшості населення із забезпеченням для осіб, які не володіли цією мовою, права на перекладача; рівноправність сторін; право обвинуваченого на захист. Проголошувалась публічність усіх судових засідань, за винятком випадків, що потребували збереження військової чи державної таємниці» [2, с. 558].

Дійсно, хоч КПК УСРР і не містив норм, які регулювали б міжнародне співробітництво у кримінальному процесі, однак він закріпив важливі засади здійснення кримінально-процесуальної діяльності, які також є фундаментальними для цього інституту. 
Не менш важливою подією в удосконаленні кримінально-процесуального законодавства УСРР стало утворення 30 грудня 1922 року Союзу PCP, складовою частиною якого вона стала. У послідуючі роки в СРСР приймаються законодавчі акти, які регулювали кримінальне судочинство у всесоюзному масштабі, зокрема «Основи кримінального судочинства Союзу PCP і союзних республік». Тому постало нове завдання - привести вітчизняне законодавство у відповідність до всесоюзного, що й було зроблено [2, с. 558].

Новий Кримінально-процесуальний кодекс УСРР (далі - КПК УСРР) було прийнято 20 липня 1927 року, його положення фактично закріпили обмеження прав людини, які держава повинна захищати та які є невід’ємним змістом міжнародно-правового регулювання.

Тому важко не погодитись із думкою В.Я. Тація, який слушно відзначив, що КПК УСРР 1927 року включав положення, які не можна назвати демократичними. Наприклад, органам слідства, прокуратури, судам заборонялося відмовляти у прийнятті до свого провадження кримінальних справ або закривати їх на тій підставі, що в КК УСРР не передбачалося покарання за суспільно небезпечне діяння, а захисник мав право брати участь у кримінальному процесі виключно зі стадії судового слідства [1].

Водночас слід зазначити, що ще в 1927 році M.Е. Шаргей роз'яснив про застосування забороненої аналогії закону в новому КПК УСРР та зауважив, що основною метою частини 3 статті 2 Кодексу було усунути можливість тяганини справи на всіх стадіях процесу, тому будь-яка судово-слідча інстанція, розглядаючи справу, повинна застосовувати закон, не зупиняючись перед його протиріччям, неповнотою чи неясністю, діючи на власний розсуд та керуючись загальними принципами закону [3, с. 7].

За таких обставин вважаю, що про впровадження інституту міжнародного співробітництва у кримінальний процес, який повинен базуватися на демократичних засадах, говорити було ще зарано. Адже для розвитку та здійснення належного співробітництва з іноземними державами є неприпустимим звуження та порушення процесуальних прав людини, а також можливість застосування закону за аналогією.

Ось чому в багатьох міжнародних актах звернено увагу на важливість прийняття державами-учасницями спільних правил у галузі взаємної допомоги у кримінальних справах, що сприятиме більшому єднанню між іï членами [4] та розвиткові співробітництва в галузі надання установами юстиції правової допомоги в цивільних, сімейних і кримінальних справах [5].

Водночас необхідно відзначити, що прийнятий у 1938 році Закон «Про судоустрій Союзу РСР, союзних і автономних республік" розвивав засади гласності судочинства, забезпечення обвинуваченому права на захист, незалежності суддів і підкорення їх тільки закону. Тому він і став однією із причин для розроблення проекту нового, більш демократичного, КПК УРСР, процес якого був призупинений Другою світовою війною [1].

Вже з настанням післявоєнного періоду «відлиги» розпочався процес поступового відходу від тоталітарної системи та приведення політичного та суспільного життя в демократичне русло.

Тому КПК УСРР 1927 року вимагав змін. А прийняття у 1958 році «Основ кримінального судочинства Союзу РСР і союзних республік" стало передумовою для розроблення нового Кримінально-процесуального кодексу УРСР (далі - КПК України), який було ухвалено 28 грудня 1960 року.

Вперше у кримінально-процесуальному законодавстві закріплено положення щодо однієї із форм здійснення міжнародного співробітництва у кримінальному провадженні - виконання запиту компетентного органу іноземної держави про міжнародну правову допомогу у кримінальній справі. Жоден із попередніх Кодексів не містив норм, які б регулювали здійснення міжнародного співробітництва у кримінальному процесі.

Так, стаття 3 КПК України 1960 року закріпила, що під час проведення на території України слідчих та інших процесуальних дій на підставі запиту (доручення) компетентного органу іноземної держави про міжнародну правову допомогу у кримінальній справі, яка перебуває у його провадженні, застосовуються норми КПК України. На прохання компетентного органу іноземної держави під час виконання на території України запиту (доручення) про міжнародну правову допомогу може застосовуватися іноземне процесуальне законодавство, якщо це передбачено міжнародним договором, згода на обов'язковість якого надана Верховною Радою України [6].

Дещо ширше питання щодо міжнародних відносин було врегульовано в Конституції України 1978 року. Так, єдиним органом законодавчої влади України є Верховна Рада України, до виключного відання якої належить ратифікація i денонсація міжнародних договорів України, а Президент України представляє Україну в міжнародних відносинах, веде переговори і підписує міждержавні та міжнародні договори України, які набирають чинності після ратифікації Верховною Радою України [7].

Хоча у Кодексі було закріплено положення про виконання запиту про міжнародну правову допомогу, однак залишалися неврегульованими багато важливих для кримінально-процесуальної діяльності питань: що ж взагалі являє собою міжнародне співробітництво у кримінальному процесі, 
яка його правова основа, який обсяг відносин ним врегульовано, які органи наділені правом його здійснення, у яких формах проявляється. Та, мабуть, одне з основних: яку ж силу мають докази, одержані національними органами від іноземних держав у процесі надання міжнародної правової допомоги та навпаки.

Тому, проголосивши 24 серпня 1991 року Незалежність, Україна взяла курс на приведення вітчизняного законодавства у відповідність до міжнародних стандартів шляхом проведення політичних, економічних та правових реформ.

До речі, важливого значення у приведенні вітчизняного кримінально-процесуального законодавства до європейських стандартів набула підписана у 1994 році Угода про партнерство і співробітництво між Україною і Європейськими Співтовариствами та їх державами-членами, де договірні сторони домовилися встановити тісні стосунки, побудовані на існуючих історичних зв'язках між ними, зважаючи на важливість розвитку зв'язків співробітництва між Союзом, його державами-членами та Україною та загальних цінностей, які вони поділяють, бажаючи встановити та розвивати постійний політичний діалог із двосторонніх та міжнародних питань, що становлять взаємний інтерес [8].

3 цього моменту Україною підписано, а Верховною Радою України ратифіковано численні міжнародні договори, які лягли в правову основу регулювання інституту міжнародного співробітництва у кримінальному провадженні, ставши частиною кримінального процесуального законодавства.

Так, Конвенція про захист прав людини і основоположних свобод 1950 року [9], Віденська конвенція про право міжнародних договорів 1969 року [10], Європейська конвенція про видачу правопорушників 1957 року [11], Свропейська конвенція про взаємну допомогу у кримінальних справах 1959 року [12], Конвенція про правову допомогу і правові відносини у цивільних, сімейних і кримінальних справах 1993 року [5], Свропейська конвенція про передачу провадження у кримінальних справах 1972 року [13], а також двосторонні договори про правову допомогу та правові відносини у цивільних, кримінальних, сімейних справах з багатьма іноземними державами визначають основні засади та умови здійснення міжнародного співробітництва та процедуру реалізації окремих його форм у кримінальному процесі.

Вирішальну ж роль в утвердженні міжнародних договорів відіграла прийнята 28 червня 1996 року Конституція України, яка проголосила, що чинні міжнародні договори, згода на обов'язковість яких надана Верховною Радою України, є частиною національного законодавства України [14].
Варто відзначити, що питання виконання та дотримання міжнародних договорів врегульовано також Законом України «Про міжнародні договори», де в ст. 15 визначено, що чинні міжнародні договори України підлягають сумлінному дотриманню Україною відповідно до норм міжнародного права. Водночас дію міжнародних договорів на території України врегульовано нормами ст. 19 Закону, де зазначено, що якщо міжнародним договором України, який набрав чинності в установленому порядку, встановлено інші правила, ніж ті, що передбачені у відповідному акті законодавства України, то застосовуються правила міжнародного договору [15].

3 вищенаведеного слідує, що міжнародним договорам України, які ратифіковано Верховною Радою України, надано пріоритетне значення, оскільки вони на національному рівні мають більшу юридичну силу, ніж КПК України. Договори забезпечують утвердження не тільки загальновизнаних прав людини та її інтересів, але й цілей, завдань і принципів здійснення належного міжнародного співробітництва та сприяють його розвитку.

Ось чому в ст. 1 чинного КПК України 2012 року закріплено положення, що кримінальне процесуальне законодавство складається з відповідних положень Конституції України, міжнародних договорів, згода на обов'язковість яких надана Верховною Радою України, Кримінального процесуального кодексу України та інших законів України [16].

Вже в наступні роки кримінально-процесуальне законодавство України стрімко розвивається. Так, ратифікація 16 січня 1998 року Європейської конвенції про видачу правопорушників 1957 року, Додаткового протоколу 1975 року та Другого додаткового протоколу 1978 року, а також 1 червня 2011 року Другого додаткового протоколу до Європейської конвенції про взаємну допомогу у кримінальних справах від 08 листопада 2001 року привела до внесення змін і доповнень у КПК України 1960 року. Норми Кодексу доповнились розділом дев'ятим, який регламентував процедуру здійснення деяких форм міжнародного співробітництва щодо видачі особи (екстрадиції), міжнародної правової допомоги у кримінальних справах та перейняття кримінального переслідування.

Переломною ж подією в утвердженні інституту міжнародного співробітництва у кримінальному процесі стало прийняття 13 квітня 2012 року нового Кримінального процесуального кодексу України, де йому присвячено окремий розділ IX «Міжнародне співробітництво у кримінальному провадженні». Норми КПК України нарешті закріпили положення щодо основних засад міжнародного співробітництва, процесуального 
порядку здійснення його форм та зафіксували ключове поняття для кримінального процесу: «що ж являє собою міжнародне співробітництво під час кримінального провадження? .

Так, ст. 542 Кодексу визначає, що міжнародне співробітництво під час кримінального провадження полягає у вжитті необхідних заходів із метою надання міжнародної правової допомоги шляхом вручення документів, виконання окремих процесуальних дій, видачі осіб, які вчинили кримінальне правопорушення, тимчасової передачі осіб, перейняття кримінального переслідування, передачі засуджених осіб та виконання вироків. Міжнародним договором України можуть бути передбачені інші, ніж у КПК України, форми співробітництва під час кримінального провадження [16].

Слід зазначити, що важливість здійснення міжнародного співробітництва визначено також і у профільних актах органів, уповноважених КПК України не тільки на здійснення кримінального провадження, а й на здійснення міжнародного співробітництва.

Зокрема, Законом України «Про прокуратуру» передбачено, що з метою реалізації своїх функцій прокуратура здійснює міжнародне співробітництво. Органи прокуратури згідно з міжнародними договорами України, згода на обов'язковість яких надана Верховною Радою України та кримінальним процесуальним законодавством України, здійснюють співробітництво з компетентними органами інших держав із питань проведення процесуальних дій під час розслідування кримінальних правопорушень, видачі осіб, які їх вчинили, перейняття кримінального провадження та з інших питань, передбачених такими договорами. У разі відсутності міжнародного договору України співробітництво у цій сфері здійснюється органами прокуратури України на підставі взаємних письмових гарантій [17].

Поліція ж, відповідно до Закону України «Про Національну поліцію», виконує в межах компетенції запити органів правопорядку (правоохоронних органів) інших держав або міжнародних організацій поліції відповідно до закону та міжнародних договорів України [18].

А одним із основних завдань Мін'юсту, відповідно до «Положення про Міністерство юстиції України», затвердженого постановою Кабінету Міністрів України 14.11.2006 року, є здійснення міжнародно-правового співробітництва, забезпечення дотримання і виконання зобов'язань, узятих за міжнародними договорами України із правових питань [19].

Висновки. Підсумовуючи вищевикладене, необхідно констатувати, що прийняття нового Кримінального процесуального кодексу України позитивно позначилося на кримінальній процесуальній діяльності органів, уповноважених на здійснення міжнародного співробітництва, тому що одними із головних чинників, що ефективно впливають на досягнення завдань у кримінальному провадженні, є його належне правове закріплення та регулювання у нормах національного законодавства, що, безумовно, сприятиме лише зміцненню законності, верховенству права та правопорядку в Україні, де на конституційному рівні людина, її життя і здоров'я, честь і гідність, недоторканність і безпека визнаються найвищою соціальною цінністю.

\section{Iimepamypa}

1. Тацій В.Я. Перебудова кримінального процесу України в контексті європейських стандартів: теорія, історія і практика». URL: http://mego.info

2. Сорока С.О., Римарчук Г.С. Кримінальний процес в Україні: історія і сучасність. Вісник Національного університету «Львівська політехніка». Серія «Юридичні науки: збірник наукових праць». 2016. № 850. С. 553-562.

3. Шаргей M.Е. Уголовно-процессуальный кодекс УССР 1927 року, текст и постатейный практический комментарий. Харьков: Юрид. изд-во НКЮ УССР. 1928. $356 \mathrm{c.}$

4. Європейська конвенція про взаємну допомогу у кримінальних справах від 20 квітня 1959 р./Верховна Рада України. URL:https://zakon.rada.gov.ua/laws/ show/995_036\#Text (дата звернення: 02.03.2021).

5. Конвенція про правову допомогу i правові відносини у цивільних, сімейних і кримінальних справах від 22 січня 1993 р./Верховна Рада України. URL: https://zakon.rada.gov.ua/laws/show/997_009 \#Text (дата звернення: 02.03.2021).

6. Кримінально-процесуальний кодекс України: Закон від 28 грудня 1960 р. № 1001_05/Верховна Рада України. URL: https://zakon.rada.gov.ua/laws/ show/1001-05\#Text (дата звернення: 08.04.2021).

7. Конституція України: Закон від 20 квітня 1978 р. № 888-IX / Верховна Рада України. URL: https://zakon.rada.gov.ua/laws/show/88809\#Text (дата звернення: 02.03.2021).

8. Угода про партнерство і співробітництво між Україною і Європейськими Співтовариствами та їх державами-членами від 14 червня 1994 р. / Верховна Рада України. URL: https://zakon.rada.gov.ua/laws/ show/998 012\#Text (дата звернення: 03.03.2021).

9. Конвенція про захист прав людини і основоположних свобод від 04 листопада 1950 р. / Верховна Рада України. URL: https://zakon.rada.gov.ua/laws/ show/995_004\#Text (дата звернення: 05.03.2021).

10. Віденська конвенція про право міжнародних договорів від 23 травня 1969 р. / Верховна Рада України. URL: https://zakon.rada.gov.ua/laws/show/995_118 (дата звернення: 05.03.2021).

11. Європейська конвенція про видачу правопорушників від 13 грудня 1957 р.

12. /Верховна Рада України. URL: https://zakon. rada.gov.ua/laws/show/995_033\#Text (дата звернення: 05.03.2021).

13. Свропейська конвенція про взаємну допомогу у кримінальних справах від 20 квітня 1959 р./Верховна Рада України. URL: https://zakon.rada.gov.ua/laws/ show/995_036\#Text (дата звернення: 05.03.2021).

14. Європейська конвенція про передачу провадження у кримінальних справах від 15 травня 1972 р. Верховна Рада України. URL: https://zakon.rada. gov.ua/laws/show/994_008\#Text (дата звернення: 05.03.2021). 
15. Конституція України: Закон від 28 червня 1996 р. №254к/96-ВР/Верховна Рада України. URL: https://zakon.rada.gov.ua/laws/show/254 (дата звернення: 11.03.2021).

16. Про міжнародні договори України: Закон від 29 жовтня 2004 р. № 1906-IV/Верховна Рада України. URL: http//zakon.rada.gov.ua/laws/show/190615\#Text (дата звернення: 12.03.2021).

17. Кримінальний процесуальний кодекс України: Закон від 13 квітня 2012 р. № 4651-VI /Верховна Рада України. URL:http://zakon.rada.gov.ua/laws/ show/4651-17\#Text (дата зверненн: 12.03.2021).

18. Про прокуратуру: Закон від 14 жовтня 2014 р. № 1697-VII/Верховна Рада України. URL: https://zakon.rada.gov.ua/laws/show/1697-18\# Text (дата звернення: 15.03.2021)..

19. Про Національну поліцію: Закон від 02 липня 2015 р. № 580-VIII/Верховна Рада України. URL: $\quad$ https://zakon.rada.gov.ua/laws/show/58019\#Text (дата звернення: 15.03.2021).

20. Про затвердження Положення про Міністерство юстиції України: Постанова Кабінету Міністрів України від 02 липня 2014 р. № 228/ Верховна Рада України. URL: https://zakon.rada.gov.ua/laws/ show $/ 228-2014-\%$ D0\% BF\#Text (дата звернення: 15.03.2021).

\section{Анотація}

Коваль O. I. Становлення інституту міжнародного співробітництва у кримінальному процесуальному законодавстві України. - Стаття.

Статтю присвячено генезі розвитку інституту міжнародного співробітництва у кримінальному процесі України в радянський та сучасний періоди. Зазначається, що у XX столітті кримінально-процесуальне законодавства формувалось під впливом історичних подій, які відбувалися на території Радянського Союзу .

Розглянуто тенденцію розвитку кримінально-процесуальних відносин, необхідним засобом упорядкування яких стала кодифікація. Незважаючи на те, що Кримінально-процесуальні кодекси УСРР 1922 та 1927 років не містили положень щодо міжнародного співробітництва у кримінальному процесі, вони закріпили важливі засади здійснення судочинства, дотримання яких $\epsilon$ необхідним для налагодженої співпраці 3 іноземними державами.

Наголошено, що з другої половини XX століття в кримінально-процесуальному законодавстві відбуваються зміни, які позитивно позначились на формуванні та утвердженні інституту міжнародного співробітництва. А з прийняттям Кримінально-процесуального кодексу України 1960 року, де вперше було закріплено положення щодо здійснення міжнародного співробітництва, розпочався процес його удосконалення.

Звернено увагу, що розвиток міжнародних відносин 3 іноземними державами, ратифікація численних міжнародних договорів, проголошення Незалежності України, прийняття Конституції України відіграли вирішальну роль у приведенні вітчизняного законодавства відповідно до міжнародних стандартів.

Встановлено, що ратифікація Європейської конвенції про видачу правопорушників 1957 року, Додаткового протоколу 1975 року, Другого додаткового протоколу 1978 року, Другого додаткового протоколу до Європейської конвенції про взаємну допомогу у кримінальних справах 2001 року та прийняття нового Кримінального процесуального кодексу України 2012 року закріпили міжнародне співробітництво як самостійний інститут у кримінальному процесуальному законодавстві.
Зазначено, що належне правове регулювання міжнародного співробітництва 3 іноземними державами у кримінальному процесі, впровадження міжнародних норм у вітчизняне законодавство є тими необхідними умовами, які сприяють утвердженню принципів законності та верховенства права, додержанню прав та законних інтересів людини і громадянина, допомагають у боротьбі зі злочинністю, а головне - слугують досягненню завдань кримінального провадження.

Ключові слова: міжнародне співробітництво, завдання кримінального провадження, міжнародна правова допомога, компетентний орган іноземної держави, права та законні інтереси особи.

\section{Summary}

Koval O. I. Formation of the institute of international cooperation in criminal procedure legislation of Ukraine. - Article.

The scientific article is devoted to the genesis of the development of the Institute for International Cooperation in the Criminal Process of Ukraine in Soviet and Modern Periods. It is noted that in the twentieth century, the criminal-procedural legislation was formed under the influence of historical events that took place in the territory of the Soviet Union.

The tendency of the development of criminalprocedural relations is considered as the necessary means of organizing which has been codification. Despite the fact that the Criminal Procedural Codes of the USRR of 1922 and 1927 did not contain provisions on international cooperation in the criminal process, but they consolidated important principles of legal proceedings, observance of which are necessary for establishing cooperation with foreign states.

There was emphasized that from the second half of the twentieth century, in criminal procedural legislation some changes took place, they positively affected the formation and approval of the Institute for International Cooperation. And with the adoption of the Criminal Procedural Code of Ukraine in 1960, where the provisions for the implementation of international cooperation were first established, the process of its improvement has began.

Attention is drawn to the fact that the development of international relations with foreign states, ratification of numerous international treaties, proclamation of Ukraine's independence, adoption of the Constitution of Ukraine played a decisive role in bringing domestic legislation in accordance with international standards.

The study has revealed that Ratification of the European Convention on the Issuance of Offenders in 1957, the Additional Protocol of 1975, the Second Optional Protocol of 1978, the Second Optional Protocol to the European Convention about mutual assistance in criminal cases of 2001 and adopting a new Criminal Procedural Code of Ukraine in 2012 is established international cooperation as an independent institution in criminal procedural legislation.

It is noted that the proper legal regulation of international cooperation with foreign states in the criminal process, implementation of international norms in domestic legislation are the necessary conditions that contribute to the establishment of the principles of legality and rule of law, compliance with the rights and legitimate interests of man and citizen, help in fighting crime, and most import they serve to the achievement of tasks in criminal proceedings.

Key words: international cooperation, the task of criminal proceedings, international legal aid, competent authority of a foreign state, the rights and legitimate interests of a person. 